\title{
Luxury car owners are not happier than frugal car owners
}

\author{
Adam Okulicz-Kozaryn • Tim Nash • \\ Natasha O. Tursi
}

Received: 2 September 2014/ Accepted: 4 January 2015/Published online: 8 February 2015

(C) The Author(s) 2015. This article is published with open access at Springerlink.com

\begin{abstract}
The happiness literature has largely omitted the topic of consumption so far. While some studies investigate the most expensive consumption item, housing, there are no studies about the second most expensive item, the car. We use 2011 wave of American Panel Study of Income Dynamics to investigate the relationship between car consumption and happiness. Car consumption is defined in two ways, as luxury cars (expensive cars, $>\$ 35 \mathrm{k}$ ) and frugal cars (inexpensive cars). We find that luxury car ownership does not make people happier than frugal car ownership. We discuss the practical implications of our findings and directions for future research. This study is limited to the USA, and results may differ elsewhere.
\end{abstract}

Keywords Happiness - Life satisfaction - Subjective well-being · Car · Conspicuous consumption · Luxury consumption

JEL Classification I31 $\cdot$ E21

\section{Introduction}

Over the past century, the automobile, or car for simplicity, has changed our lives. Commuting, shipping, traveling, and emergency services are all possible or greatly improved due to a car. The car provided freedom, independence, and convenience. On the other hand, air and noise pollution, suburban sprawl, obesity, congestion, and traffic accidents result from car use as well. Fundamentally, the car has transformed the built environment, especially that of recently developed areas outside of the

\footnotetext{
A. Okulicz-Kozaryn $(\bowtie) \cdot$ T. Nash $\cdot$ N. O. Tursi

Camden, NJ, USA

e-mail: adam.okulicz.kozaryn@gmail.com
} 
Northeastern United States. Unlike in Europe, America's infrastructure is designed around the car including not only roads and parking lots, but also single-use zoning, suburban sprawl, shopping malls, and so forth. Did car make us happy?

The topic of cars and happiness ${ }^{1}$ is interesting for several reasons. First, it may seem obvious to people, especially males, that car, especially a luxury car, brings about happiness. Think of a shiny, fully loaded model of Lexus, BMW, Audi, or any other overpriced car. ${ }^{2}$ It is easy to imagine that happiness results from such a purchase, and that is arguably a major reason to pay extra for these cars-their purchase promises happiness. It may appear that such a luxury car would bring about much more happiness than a frugal car, say a Toyota Corolla or a Honda Civic. We will argue here that this common wisdom is wrong.

Buying a car is a key financial decision for most people, as it is the single largest purchase (after housing). ${ }^{3}$ Accordingly, many people get themselves into financial trouble by purchasing cars they cannot afford. There are other interesting aspects as elaborated below. The car is related to policy, transportation, development, and sustainability/environmental debates. Yet, there is not a single study exploring the relationship between car and happiness. ${ }^{4}$

Fundamentally, it is thought-provoking to study the relationship between happiness and any (not only car) consumption, because we are all consumers, and arguably, we usually expect some happiness from our purchases even if we do not think about happiness, but comfort, convenience, and so forth. Consumption is related to personal income, and there is much attention given to income in relation to happiness, but consumption is virtually not studied at all. Yet, what determines actual quality of life or well-being or happiness is rather consumption, not income. Plainly speaking, you cannot eat money-money only makes us happy because we

\footnotetext{
1 Happiness is briefly defined in Sect. 4, we use this term for simplicity instead of a more scientific term subjective well-being (SWB). Also, we mean rather overall life satisfaction (cognition) than momentary happiness (affect).

2 As explained later, these cars are overpriced because consumer pays not only for a product (car), but also for conspicuous or wasteful manifestation of superiority as explained later. In another sense, these cars are not overpriced because consumer pays for exclusivity-luxury cars are attractive because they manifest the ability to pay what others can't. But from economic or sustainability perspective, this is waste.

3 Surprisingly cars are not getting cheaper. The first affordable car, Model T, was only $\$ 3.5 \mathrm{k}$ (in today's dollars), but today's affordable cars cost over $\$ 10 \mathrm{k}$. Luxury cars became more expensive, too. For instance, Porsche 911 used to cost \$47k (also in today’s dollars) in 1965, now it sells for \$82k. See http:// www.forbes.com/sites/quora/2013/05/07/why-are-cars-not-getting-cheap-even-with-better-economies-ofscale/ and http://jalopnik.com/5953080/how-inflation-has-jacked-up-the-prices-of-your-favorite-cars/. And yet the market for luxury cars is thriving (e.g., Economist 2013b). Luxury cars are so-called Veblen goods, which become more desirable as they get more expensive.

4 There are studies including car possession dummy variable in their happiness models-yet, all of them treat car purely as a control variable and accordingly do not give much thought, neither explore it. For details, see World Database of Happiness: Correlational Findings on Happiness and POSSESSIONS Subject Code: P10, specifically P10.2.2.2 at http://www1.eur.nl/fsw/happiness/hap_cor/top_sub.php?code=P10. DeLeire and Kalil (2010) operationalize car consumption in one variable as vehicle purchase (including related expenditures such as insurance, maintenance), and find no effect. Also, see a recent review of research on hedonic consumption (Alba and Williams 2013), which does not mention a single study about a car.
} 
can use it for consumption or imagine resulting consumption. ${ }^{5}$ Some economists actually recognize that consumption is a better measure of permanent income and material well-being than income [Meyer and Sullivan 2003, cited in DeLeire and Kalil (2010)]. Like income, consumption is a policy topic-there is an ongoing discussion about taxing it-we already tax alcohol and tobacco, there are proposals to tax soda, and luxury consumption could be taxed as well. Indeed, even conservative Milton Friedman, who supported small government, has noted that if government needed additional revenue, a progressive consumption tax would be the best way to raise it (Frank 2010).

As recently lamented by Frey et al. (2014), there are many empirical happiness studies, but they do not focus enough on theory. Before we analyze the data for this research, we will briefly discuss broad economic, social, and environmental implications of car use and possible causal pathways from car consumption to happiness. We do not claim causality in this purely correlational or observational study. Yet, as persuasively pointed out by labor economist Andrew Oswald (e.g., Blanchflower and Oswald 2011; Oswald 2014), correlational studies are not without merit despite what many economists think-many scientific breakthroughs were first discovered in observational studies-for instance that smoking is related to cancer. Experiments are now in fashion in economics, and it is often overlooked that they suffer from many critical problems that are not inherent in observational studies such as lack of external validity, small sample size, artificial laboratory setting, and forced imaginary roles, such as a person pretending to be a company or imagining winning a lottery. For a discussion, see for instance Pawson and Tilley (1997).

In short, we contribute to the literature by conducting the first study of the effect of car consumption on happiness. We report first results, and encourage further investigation into the happiness derived from any, not only car, consumption.

\section{Why a luxury car does not buy much happiness}

From an economic standpoint, car use is desirable-it contributes to economic growth. Indeed, even traffic congestion contributes to economic growth (Stiglitz et al. 2009). Likewise, any luxury consumption is preferable-the more we consume, the higher the economic growth (at least in the short run). Yet, economic growth, what mainstream economists usually forget, is not the only ultimate outcome of interest. There is also freedom, physical and mental health, happiness, and so forth. Taking the happiness perspective, it is not immediately obvious whether a car makes us happy. On the one hand, cars arguably add convenience, comfort, independence, freedom, coziness, travel speed, security, and control (e.g., Steg 2003). On the other hand, cars pollute [pollution decreases happiness, e.g.,

\footnotetext{
5 Of course, strictly speaking, income contributes to happiness in addition to consumption-savings and investment also do affect our well-being by offering peace of mind, thrill of adventure, power/domination/envy premium, and other benefits. Furthermore, often it is not consumption per se that results in happiness, but other factors that consumption enables, notably social capital. For instance, car has been argued to increase happiness because it increases social connectedness (DeLeire and Kalil 2010).
} 
Weinhold (2012), Welsch (2005)] and encourage suburban sprawl (e.g., Duany et al. 2001), which in turn forces commuting. Long commute is the least enjoyable thing a person can do (Kahneman et al. 2004). ${ }^{6}$ Finally, luxury cars cost money and, hence, time. This study uses the happiness yardstick to evaluate cars-do cars make us happy? And do luxury cars make us happier than frugal cars?

Based on personal observations we hypothesize that frugal cars (e.g., Toyota Corolla or Honda Civic) make us happy and luxury cars (e.g., Lexus or Audi) do not contribute much happiness above what a frugal car delivers. Theoretically, our hypothesis is based on an old idea of diminishing marginal utility (or happiness) each additional item consumed brings less happiness-say the first cake increases your happiness by 1 , the second by .5 , the third by .25 , and so forth, and at some point, you get sick and experience negative utility or unhappiness. It is the same with cars. Having a car v no car helps immensely $;{ }^{7}$ having a good car v a junk car helps quite a bit, but having a luxury car over a good car does not help or may even hurt (like too many cakes). For instance, having a luxury car is likely to make you more worried about it (being stolen, scratched, etc), and you need to work extra to pay it off. It is especially a burden if you bought something you cannot afford. American consumers tend to buy things they cannot afford, and worse, they buy things they do not need, e.g., luxury cars.

A luxury car provides about the same convenience or comfort as a frugal car does. Leather and heated seats, or fashionable shapes and colors are not likely to be important for human flourishing. In short, we hypothesize that there is likely to be a greater happiness gap between people without a car and people with a frugal car, than between people with a frugal car and people with a luxury car. Note that it costs at least the same or more to change from a frugal car to a luxury car than to change from no car to a frugal car. Fundamentally, economists would argue that there is an opportunity cost. But the specific idea here is little different: Consumers tend to underestimate how much time consumption costs them, especially if consumption is technologically advanced or superior in some other way. It somehow (falsely) appears that it is worth the extra price or labor to earn it. This point was beautifully made by Thoreau, who incidentally used a transportation example: ${ }^{8}$

One says to me "I wonder that you do not lay up money; you love to travel; you might take the cars and go to Fitchburg today and see the country." But I am wiser than that. I have learned that the swiftest traveler is he that goes

\footnotetext{
${ }^{6}$ Kahneman et al. (2004) only looked at everyday experiences. He did not look at slavery, torture, or other nasty things that must be even less enjoyable than commute.

${ }^{7}$ It is true in most areas, but in some areas, notably in dense areas, such as New York, NY, car may actually be a hassle.

${ }^{8}$ Of course, technology has improved a lot since Thoreau's times and his example is literally false, yet it is still valid in terms of abstract or general meaning. These days it makes more sense to work and pay for flight from one coast to another, than not to work and walk. But the idea is simply that we tend to forget about the opportunity cost, and it is especially troublesome that we often do it for wrong reason-to use fancy and glitzy train, as in Thoreau's time or to use a luxury automobile as in our times without really thinking about what we are doing and what we are foregoing and how that affects our utility or well-being or happiness.
} 
afoot. I say to my friend, suppose we try who will get there first. The distance is thirty miles; the fare ninety cents. That is almost a day's wages. I remember when wages were sixty cents a day for laborers on this very road. Well, I start now on foot and get there before night; I have travelled at that rate by the week together. You will in the mean while have earned your fare and arrive there some time tomorrow, or possibly this evening, if you are lucky enough to get a job in season. Instead of going to Fitchburg, you will be working here the greater part of the day.

You can buy a luxury Lexus for $\$ 50 \mathrm{k}$ or a frugal Corolla for $\$ 25 \mathrm{k}$; the difference is $\$ 25 \mathrm{k}$ - enough to buy 10 vacations at $\$ 2.5 \mathrm{k}$. ${ }^{9}$ However, what is more fundamental and often overlooked is that buying a Lexus costs time (spent working to earn it), and the amount of it depends on your salary. Even for rich people (say annual income $\approx \$ 250 \mathrm{k}$ ), it still makes a difference to spend $\$ 50 \mathrm{k}$ versus $\$ 25 \mathrm{k}$; for super rich (say annual income $>\$ 1 \mathrm{~m}$ ), it does not make much difference; but for the middle class (annual income $\approx \$ 50 \mathrm{k}$ ), it makes a big difference-if a person makes $\$ 10$ per hour after tax, ${ }^{10}$ then a Lexus costs 2,500 h over a Corolla, which translates into 312 extra days of work ( $8 \mathrm{~h}$ per day). Excluding weekends and holidays, it is well above a year. This is a lot of foregone time! But even for a rich person, who makes say $\$ 100$ per hour after tax, it would cost her well above a month of timenot an insignificant cut. A recent survey found that a median income of a luxury car owner is surprisingly low at $\$ 100,000$ per annum (Sullivan 2014). Still, all the extra time spent working to buy a luxury car may be worth it, if it buys happiness. If it does not, what is the point?

If we can establish that luxury cars do not contribute much to happiness, would taxing luxury consumption be justified? Probably. We should keep in mind that resources are limited. For instance, money spent on Lexuses is not spend on food or other necessities. Furthermore, conspicuous consumption results in an arms racepeople want to outcompete others with ever more luxury items and in doing so create more "wants" in society (Frank 2012).

A related argument to scarcity of resources is about sustainability and the environment. If cars, and especially larger, more polluting SUVs (sport utility vehicles), do not bring much happiness, but pollute and destroy the environment significantly, we should simply tax their use. If on the other hand, cars contribute significantly to our happiness, then the debate is open. What is more important, our happiness or pollution? We will not pursue this debate further; we just want to signal that pollution is arguably an important negative externality that needs to be

\footnotetext{
9 This is approximate pricing-the point is that a new luxury car costs at least twice as much as frugal car in the USA. For instance, as of Aug 2014, frugal Toyota Corolla is listed for \$16.8k, frugal Honda Civic costs $\$ 18.4 \mathrm{k}$, but luxury Lexus (IS) costs $\$ 36.5 \mathrm{k}$ and Audi (A3) costs $\$ 30 \mathrm{k}$ (to be conservative in luxuryfrugal price comparisons, all cars are the cheapest versions. If most expensive versions were compared, the difference would be larger).

10 Median household income in the USA is about \$50,000 annually, and many of the households in that range have two incomes. Two people who both work full time for $\$ 12$ per hour would make about $\$ 24,000$ each ( $\$ 12$ per hour $* 40$ h per week $* 50$ weeks (assume 2 weeks vacations)) and have $\$ 48,000$ combined income, which is slightly below US median household income. All numbers in this footnote are before-tax.
} 
taken into account along with happiness when evaluating cars. In fact, by one estimate, car emissions kill more people than car accidents do (Jaffe 2014). Even Milton Friedman would tax car pollution (McMahon 2014).

From an environmental sustainability perspective, cars are a problem. They obviously pollute, but they also correlate with wasteful urban sprawl (Kay 1997; Duany et al. 2001). In the USA, it appears, car penetration of the market already peaked. According to OICA, ${ }^{11}$ the number of passenger cars in use has been declining since 2008. But worldwide, it is growing. In 2005, there were $652 \mathrm{~m}$ passenger cars in use, and in 2012, there were $833 \mathrm{~m}$ cars. And there is room for increase - the motorization rate (vehicles/1,000 inhabitants) in 2012 was 791 in the USA, 563 in the European Union, but only 79 in China and 18 in India. ${ }^{12}$ It will be an environmental problem when poor countries like India and China keep on adding more people to the middle class and if that middle class is consuming cars like the US middle class. In China, the luxury car market has grown over the past decade at $36 \%$ a year (26\% yearly increase for all cars). Other BRIC countries (Brazil, Russia, India, and China) also have a "big appetite" for luxury cars (Economist 2013b). In developed countries, on the other hand, there appears to be a shift happening toward more frugal and environmentally friendly cars. America often sets the consumer trends in the World, and California sets the trends in Americathe Toyota Prius tops the Honda Civic as California's bestselling vehicle. ${ }^{13}$ We will not purse this line of thought further-for more elaboration on the topic of environmental sustainability and consumption, see Bergh (2011), Daly (2013), Kallis (2011), Kallis et al. (2012). On the other hand, what is often forgotten is that transportation was by no means clean before the car. Cities, for instance, used to drown in horse manure (Morris 2007; Levitt and Dubner 2010). In that sense, the car is a cleaner solution than a horse, but public transportation is even cleaner.

While there is no literature about the relationship between car and happiness, there is literature about nonpecuniary v pecuniary consumption. For instance, see work by Frank (2004, 2005, 2012). In short, we should buy experience (e.g., vacation, bowling) not things (e.g., Lexuses, Audis) (Kumar et al. 2014). The problem with satisfaction received from material consumption is that it stimulates needs. A person is on a "hedonic treadmill" chasing luxuries but never catching lasting happiness. ${ }^{14}$ Experience consumption (e.g., bowling, fishing, swimming) does not suffer from this problem or at least suffers to a lesser degree. While luxury consumption does not result in lasting happiness (e.g., Linssen et al. 2011), it may actually result in short-run happiness, especially if a person is materialistic (Hudders and Pandelaere 2012). Materialism is related to luxury consumption, but beyond the

\footnotetext{
11 See http://www.oica.net/category/vehicles-in-use/. OICA stands for Organisation Internationale des Constructeurs d'Automobiles; in English: International Organization of Motor Vehicle Manufacturers.

12 See http://www.oica.net/category/vehicles-in-use/. For more discussion, see Economist (2013a).

13 See http://articles.latimes.com/2013/jan/23/business/la-fi-autos-prius-20130123.

14 Which does not mean that luxury car buyers do not obtain other outcomes of interest than happiness, for instance pride. Just like New Yorkers do not get happiness by living in New York, NY, but they get pride (Balducci and Checchi 2009).
} 
scope of this study - for a brief discussion of it and its relationship to happiness, see Hudders and Pandelaere (2012).

This section ends as it started-with popular wisdom about luxury car resulting in happiness. There is a sense that a car, especially a luxury car, will bring you happiness by means of making you special, outstanding, and so forth, or by signaling or reaffirming these qualities. A luxury car is a status symbol-it signifies high social rank or class. ${ }^{15}$ Simply speaking, a luxury car is intended to show that you are better than others-say accomplished or arrogant. McFerran et al. (2014) put it this way: Luxury consumption may be sought out of heightened feelings of accomplishment (and not arrogance), but it instead signals arrogance to others (rather than accomplishment). Yet, whatever the reasons are for luxury consumption, benign (accomplishment) or malicious (arrogance), it doesn't change the fact that luxury consumption or conspicuous consumption is wasteful (in an economic or monetary sense). ${ }^{16}$ Indeed, Veblen who coined the term "conspicuous consumption," also has argued that conspicuous consumption is waste (Veblen 2005a, b). Yet much of the marketing peddles luxuries implying something quite opposite to waste, something great and glorious. Lexus, for instance, has really make-you-feelspecial commercials: "F provokes lust. It unleashes wrath. It incites envy. And it elicits pride. Temptation comes in many heart pounding forms, but only one letter. F. The performance mark from Lexus." ${ }^{17}$ Hence, if you buy a Lexus, you will also get lust, wrath, envy, pride, and people buy it. Another reason to buy a Lexus is to show that you are pursuing "perfection," as another commercial puts it, ${ }^{18}$ so arguably by virtue of driving a Lexus, you are in some way closer to perfection, or at least you are in pursuit. It remains for future research to determine whether Lexus owners are more "perfect" than those buying cheap cars, but in this study, we test whether Lexus and other luxury car owners are happier than others.

\section{When a luxury car does buy happiness}

We are not against cars in general. On the contrary, we think that frugal cars may bring more happiness than public transportation (especially assuming no heavy traffic and a reasonable commute) as suggested by Morris and Guerra (2014). Furthermore, as explained in this section, there are situations where a luxury car probably does result in lasting happiness.

\footnotetext{
15 Car even remains a status symbol when it is a ride-sharing service such as Uber, that is, your status is higher if a car that drops you off is luxury as opposed to ordinary (Ryzik 2014). Likewise, car rentals or luxury taxis or limousines boost status-people pay extra for them because they buy status.

${ }^{16}$ It could be counterargued that yesterday's luxuries such as a toilet or hot water are today's necessities, and in that sense, luxury consumption simply signifies progress. This is arguably true with respect to many goods, but it is false with respect to many other goods. A key distinction between progress and waste is usefulness. While toilet over no toilet is useful, toilet made of gold over toilet made of cheap plastic is waste, and so forth.

17 See https://www.youtube.com/watch?v=pqsPdpoCedo.

18 See https://www.youtube.com/watch?v=16hPBsw2Uy4.
} 
There are several exceptions when we think that a luxury car does buy happiness. For instance, imagine ${ }^{19}$ a person dreaming her entire life about a ' 57 Chevy, and then she finally owns it. If you are truly passionate about some car, a purchase of that car may result in lasting happiness, but if you just bought a luxury car because everybody at your workplace does, or to impress someone, or for other similar reason, then it would likely not result in lasting happiness. Arguably, many people rationalize other needs such as pride, success, or accomplishment signaling with genuine need. That is, they have some wants, but they justify or rationalize them as needs.

Also, people may not have to necessarily dream about a specific car their whole life but simply "be into cars"- - a passionate mechanic (not every mechanic is passionate), or someone who passionately participates in racing. If you have genuine passion or interest, then again, we speculate (for future research, not tested here) luxury cars are likely to result in lasting happiness. But people who really dream about some car or "are really into cars" are just few percent of population at most, and likely a small fraction of a percent. What makes a fake impression that most people derive happiness from a luxury car is simply that luxury cars are a popular want in consumerist society and a status symbol, and because status is related to happiness, it appears that its symbols are related as well. Arguably, advertising and marketing contribute to generating wants disguised as needs-people think they really need a luxury item not realizing that it is a want. On the other hand, some people may need luxury cars for objective reasons - for instance, their line of work or their business may benefit from it, say their clients or partners would treat them more seriously (e.g., Economist 2013b). A luxury car may also benefit its owner by raising her confidence and self-esteem, however illusory or shallow it may be. Yet another explanation is, as probably many luxury car owners would put it, they may not necessarily buy luxury cars because they really need it (as many people really need some car to get around), but they may justify the price premium with quality, craftsmanship, and other similar arguments. This may be true for some people. Another justification of a luxury car purchase is when a person spends a lot of time in a car, say uses it as a "mobile office," then extra features may matter more for wellbeing than in a typical case. The key distinction, not tested here, is not really luxury $\mathrm{v}$ non-luxury, but why you buy it. ${ }^{20}$ If you really need it or really want it (being passionate about cars) for what it is, then buy it. If you think you need it by rationalizing your want, then a luxury car probably will not increase your happiness. Again, we think that the vast majority of people do not really need luxury cars. Yet, even those who really need them may not derive lasting happiness from them, because humans simply get used to material possessions (hedonic adaptation). ${ }^{21}$

\footnotetext{
19 See http://www.today.com/parents/keys-happiness-son-surprises-dad-57-chevy-57th-birthday-2D7976 9669 and there are multiple similar stories when people are probably happy by spending a fortune on a car, e.g., http://www.forbes.com/2005/03/04/cz_ms_0304guide.html, but this is a tiny minority.

${ }^{20}$ It will be difficult to test in the future research, because, as argued above, people are likely to rationalize their wants as needs.

21 Yes, we also get used to frugal cars, but these cars cost half of the price of a luxury car or less.
} 


\section{Happiness}

The audience of this journal is familiar with the concept of happiness, and hence it will be described only briefly ${ }^{22}$ - happiness can be defined as "people's cognitive and affective evaluations of their lives" (Diener et al. 1995, p. 851), which is virtually the same as Veenhoven's (2008, p. 2) definition: “overall judgment of life that draws on two sources of information: cognitive comparison with standards of the good life (contentment) and affective information from how one feels most of the time (hedonic level of affect)." Some scholars make a distinction between happiness and life satisfaction-Life satisfaction refers to cognition and happiness refers to affect. Life satisfaction is a cognitive aspect of happiness (e.g., Dorahy et al. 1998). We will not pursue this dichotomy because we have only one survey item, which likely captures mostly life satisfaction but also happiness to some degree. Therefore, the overall happiness definition by Veenhoven (2008) seems most appropriate and we will use the terms "happiness" and "life satisfaction" interchangeably to denote a more scientific term "subjective well-being (SWB)." Happiness measure, even though self-reported and subjective, is reliable and valid (e.g., Tella and MacCulloch 2006; Myers 2000), and closely correlates with similar objective measures of well-being such as brain waves (Layard 2005). Finally, to avoid confusion, happiness is very different from customer satisfaction about some product, say car. As explained above, happiness is a very broad evaluation of life as a whole, whereas customer satisfaction is satisfaction or merely an evaluation of some service or a product. In that sense, it is not contradictory that consumers may be more satisfied with luxury cars, ${ }^{23}$ and yet not happier.

Importantly, there are three major theories, and they are all relevant with respect to car consumption. The adaptation theory (Brickman et al. 1978) argues that there is adjustment to external circumstances and we are on a "hedonic treadmill." "The more one has the more one wants, since satisfactions received only stimulate instead of filling needs"(Durkheim [1895] 1950). We get used to (adapt to) a car, too-you have probably experienced it yourself_-were thrilled with a new car for a few days, happy for a few weeks, but after a few months, it does not make much difference. The multiple discrepancy theory (Michalos 1985) states that happiness is a result of social comparison or a comparison to various standards. I compare my car to those in the parking lot at my workplace and in my residential area, even on the road. I compare it to standards - for instance, what kind of a car is a social scientist in the USA supposed to drive? I am happy to see many Priuses in the parking lot of my university - other social scientists, like me, prefer small and "green" cars. Lawyers and business school faculty, on the other hand, appear to like luxury cars, and so do physicians. One of them told me that she drives a Lexus because that's what physicians drive. In that sense, a lack of Lexus may be an obstacle to happiness, because one needs it to be socially accepted and connected, and social capital is key

\footnotetext{
${ }^{22}$ For more complete treatments, see any of the following reviews: Helliwell (2014), Ballas (2013), Diener (2013), Diener et al. (2013), Veenhoven (2012), Erdogan et al. (2012), Proctor et al. (2009), Frey and Stutzer (2002).

23 For instance, J.D. Power Customer Service Index indicates higher satisfaction for luxury brands than for mass market (http://www.jdpower.com/press-releases/2014-us-customer-service-index-csi).
} 
for happiness (e.g., Putnam 2001). The needs/livability theory (Veenhoven and Ehrhardt 1995; Veenhoven 2014) posits that happiness results from objective living conditions and from fulfillment of our needs, and predicts that luxury cars do not contribute to happiness more than frugal cars-both will take you from point A to point B. No wonder that a creator of livability theory, Ruut Veenhoven, drives a frugal Volkswagen, and not a luxury Mercedes. For a recent discussion of adaptation and comparison, see Frey et al. (2014).

\section{Data and results}

This study uses the Panel Study of Income Dynamics (PSID) data set. The happiness question reads "Please think about your life as a whole. How satisfied are you with it? Are you completely satisfied, very satisfied, somewhat satisfied, not very satisfied, or not at all satisfied?" and it is measured on a scale from 1 = "Not at all satisfied" to $5=$ "Completely satisfied." This question was first asked in 2009 and then again in 2011; 2013 data are not available yet, and hence, we use a cross section only for 2011, the most recent year available. There is very little variation in car ownership from 2009 to 2011, and hence, it is left for future research to take advantage of the panel design, when more data become available. Even though happiness is ordinal, Ferrer-i-Carbonell and Frijters (2004) showed that treating it as cardinal in regression does not change results substantially, and therefore, we use OLS. Control variables are those typically used in happiness research (e.g., OkuliczKozaryn 2011). This study focuses on the first car in a household, which is the newest car, and hence, it arguably should have the largest impact on happiness. Because it seems not possible to determine which car belongs to which respondent within a household or is most frequently used by that respondent, we will also examine a total number of cars in a household. Variable definitions and summary statistics are in "Appendix."

First, we follow the extant literature by simply treating car ownership as a binary variable (per family, not per person) — car v no car (OWN CAR)—results are set in Table 1. Column a1 shows a bivariate relationship — as expected owning a car pays off in happiness. This result, however, is biased because owning a car correlates with wealth. Column a2 adds TOTAL FAMILY INCOME and car effect size drops substantially. In column a3, further controlling for affluence, whether a person owns A DWELLING (base case), RENTS A DWELLING, or OTHER THAN OWN/RENT A DWELLING, kills significance on OWN CAR. Simply by taking into account income and housing situation, a car does not contribute to happiness. Finally, column a4 adds other key predictors of happiness, AGE, AGE SQUARED, MARRIED, and (self-reported) HEALTH. Other controls are also added, because they may matter for the car-happiness relationship. NUMBER OF CHILDREN IN HOUSEHOLD ${ }^{24}$ arguably matters with respect to the car-the car may add more convenience if there are children in a family. As

\footnotetext{
${ }^{24}$ Note, PSID original definition uses term family unit (FU): "The FU is defined as a group of people living together as a family. They are almost always related by blood, marriage, or adoption. And they must all be living in the same HU," where HU is a household unit—see https://psidonline.isr.umich.edu/ Guide/FAQ.aspx?Type=5\#90.
} 
Table 1 OLS regression of happiness

\begin{tabular}{|c|c|c|c|c|c|c|c|c|}
\hline & a1 & $\mathrm{a} 2$ & $\mathrm{a} 3$ & $\mathrm{a} 4$ & b1 & $\mathrm{b} 2$ & b3 & $\mathrm{b} 4$ \\
\hline Own car & $0.15^{* * *}$ & $0.08 *$ & -0.02 & $-0.11 * *$ & & & & \\
\hline 1 car & & & & & -0.03 & -0.05 & $-0.09 *$ & $-0.13 * * *$ \\
\hline 2 cars & & & & & $0.26 * * *$ & $0.20 * * *$ & $0.10^{*}$ & -0.05 \\
\hline 3 cars & & & & & $0.30 * * *$ & $0.22 * * *$ & $0.10^{*}$ & -0.02 \\
\hline $\begin{array}{l}4 \text { or more } \\
\text { cars }\end{array}$ & & & & & $0.22 * * *$ & $0.12 *$ & -0.01 & $-0.15^{*}$ \\
\hline $\begin{array}{l}\text { Total } \\
\text { family } \\
\text { income }\end{array}$ & & $0.00 * * *$ & $0.00 * * *$ & $0.00 * * *$ & & $0.00 * * *$ & $0.00 * * *$ & $0.00 * * *$ \\
\hline $\begin{array}{l}\text { Rent a } \\
\text { dwelling }\end{array}$ & & & $-0.23 * * *$ & $-0.08 * *$ & & & $-0.18^{* * *}$ & $-0.07 * *$ \\
\hline $\begin{array}{l}\text { Other than } \\
\text { own/rent } \\
\text { a } \\
\text { dwelling }\end{array}$ & & & $-0.34 * * *$ & $-0.20 * * *$ & & & $-0.29 * * *$ & $-0.19 * * *$ \\
\hline $\begin{array}{l}\text { Number of } \\
\text { children } \\
\text { in } \\
\text { household }\end{array}$ & & & & $0.04 * * *$ & & & & $0.04 * * *$ \\
\hline Health & & & & $0.20 * * *$ & & & & $0.20 * * *$ \\
\hline Male & & & & -0.05 & & & & $-0.06^{*}$ \\
\hline Married & & & & $0.30 * * *$ & & & & $0.28 * * *$ \\
\hline Age & & & & $-0.03 * * *$ & & & & $-0.03 * * *$ \\
\hline Age2 & & & & $0.00 * * *$ & & & & $0.00 * * *$ \\
\hline $\begin{array}{l}\text { State } \\
\text { dummies }\end{array}$ & No & No & No & Yes & No & No & No & Yes \\
\hline Constant & $7.70 * * *$ & $7.67 * * *$ & $7.89 * * *$ & $7.47 * * *$ & $7.70 * * *$ & $7.68 * * *$ & $7.85 * * *$ & $7.50 * * *$ \\
\hline$N$ & 8,902 & 8,901 & 8,901 & 8,871 & 8,902 & 8,901 & 8,901 & 8,871 \\
\hline
\end{tabular}

${ }^{+} p<0.10 ; * p<0.05 ; * * p<0.01 ; * * * p<0.001$

hypothesized earlier, a car may have a differential effect by gender-males' happiness may depend more on a car than that of females; hence, the MALE dummy is added to a model. Also a dummy for state is added-not only are US states vastly different, but also a car is a virtual necessity in most states in the middle of the country, while in the North East or on the West Coast it may actually be a hassle due to heavy traffic, expensive parking, and relatively decent public transportation. When these controls are added in column a4, own CAR becomes negative. Hence, the apparent positive bivariate relationship between car and happiness is spurious-it disappears or even becomes negative when controlling for relevant predictors of happiness. Let's explore further-the following sets of models will use different operationalizations of car consumption following the same sequential adding of controls in columns 1 through 4. 
Table 2 Categories of cars by price range

\begin{tabular}{lllc}
\hline Price range & Name & Description & Frequency \\
\hline$\$ 0$ & No car & No car & 1,464 \\
$\$ 0-5 \mathrm{k}$ & Junk car & More trouble than help & 700 \\
$\$ 5-15 \mathrm{k}$ & A car that works & This should increase happiness & 808 \\
$\$ 15-23 \mathrm{k}$ & Reliable car & This should increase happiness even more & 668 \\
$\$ 23-35 \mathrm{k}$ & Very good car & But not much more happiness from it than & 583 \\
& & that form a reliable car & 191 \\
$\$>35 \mathrm{k}$ & Luxury car & No happiness from its use over cheaper cars, & \\
& & perhaps unhappiness due to opportunity & \\
& & cost, etc
\end{tabular}

Only using cars that were purchased in 2009 or later: As argued earlier, the effect from a car is likely to disappear over time. Also, for simplicity, only using price for the newest car

We turn to number of cars per family, which are distributed as follows: 0 cars (16\%), 1 car (34\%), 2 cars (33\%), 3 cars (12\%), 4 cars or more $(5 \%)$.

Results are also set in Table 1 (columns b1-b4). Contrary to expectations, families with one car are no happier than people without car (base case; using public transportation), and less happy than people with more cars. When controlling for income (b2), the happiest people are those with 2 or 3 cars (per family), but not more than that. This pattern persists when controlling for the housing situation (b3). Finally, when looking at the most complete set of controls in column b4, there are no significant differences across the number of cars dummies, and no quantity of cars results in more happiness than no car.

Two previous operationalizations of car consumption are limited, because cars differ enormously - there are cars that barely work, and such cars may actually generate misery, and there are cars more expensive than houses. The main focus of this paper is luxury consumption of cars. We simply define a luxury car as an expensive car. Car price has been broken into dummies. Table 2 shows price categories along with a brief description or motivation for a category and frequencies. Regression results are set in Table 3. There are fewer observations because price data are missing for many cars.

The results are mostly as expected, but a few interesting patterns emerge. In column c1 (without controls) — owning a junk car $(\$ 0-5 \mathrm{k})$ is no better than owning no car, but a luxury car $(\$>35 \mathrm{k})$ brings more happiness than a frugal car $(\$ 5-35 \mathrm{k})$. This unexpected result is due to omitted wealth from this regression-again, it is not luxuries but wealth that contributes to happiness. In column c2, a basic control for wealth, income, is introduced and it already makes the coefficient on luxury car smaller in magnitude than very good car (\$23-35k). Adding more wealth controls (housing situation) in column c3, makes luxury car insignificant. Finally, with a full set of controls in column $\mathrm{c} 4$, none of the price dummies remain significant, but cars within two mid-range categories $(\$ 15-35 \mathrm{k})$ contribute to happiness the most. We have also tried different cutoff points, and the results were similar.

Finally, as a robustness check, we control for an additional variable. As argued earlier with respect to the "hedonic treadmill," it is important to take into account 


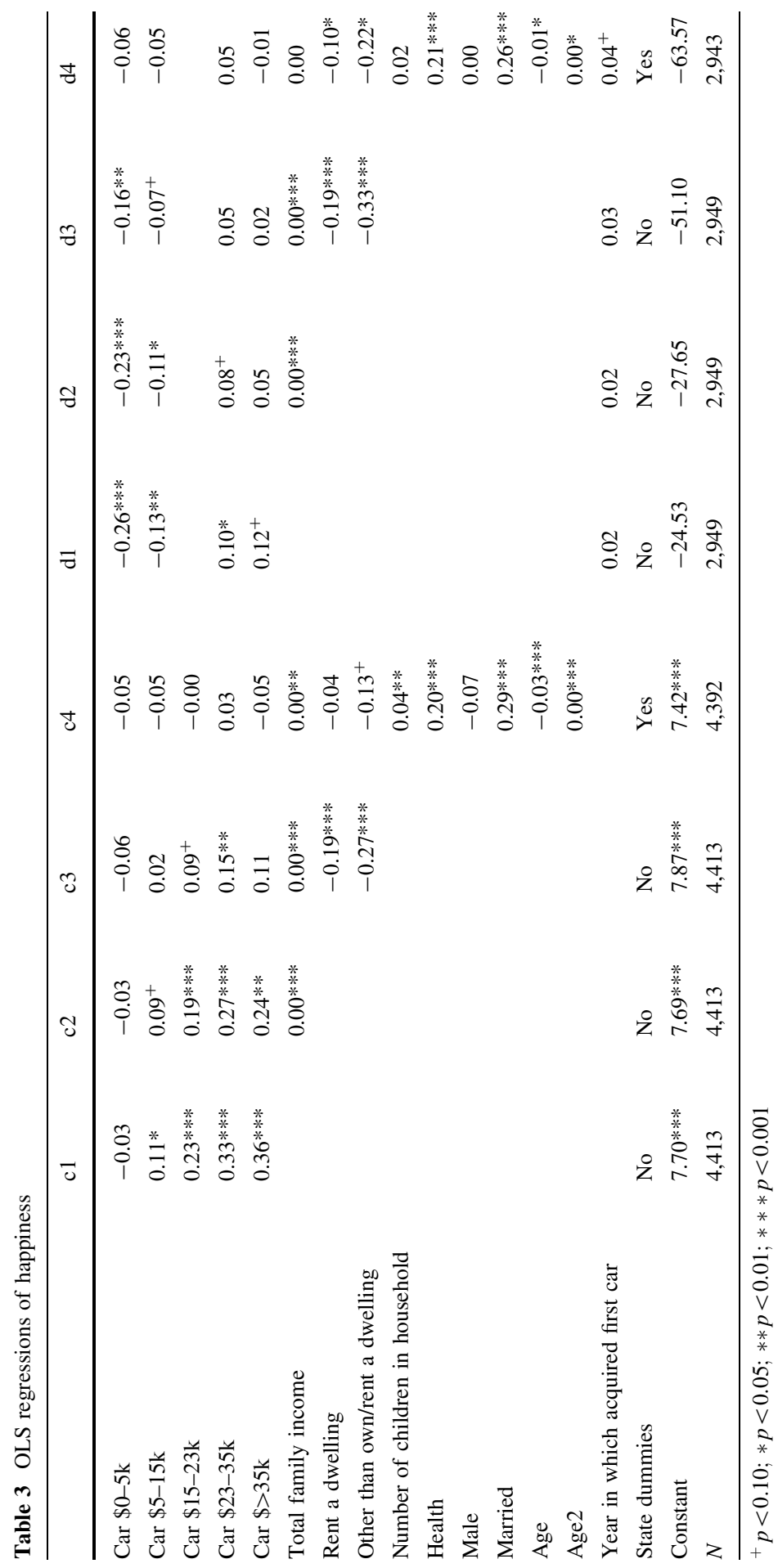


Fig. 1 Expected versus experienced utility (or happiness). We make decision about income (or consumption) based on expected or decision happiness, but the experienced or true happiness is lower when we achieve greater income or consumption

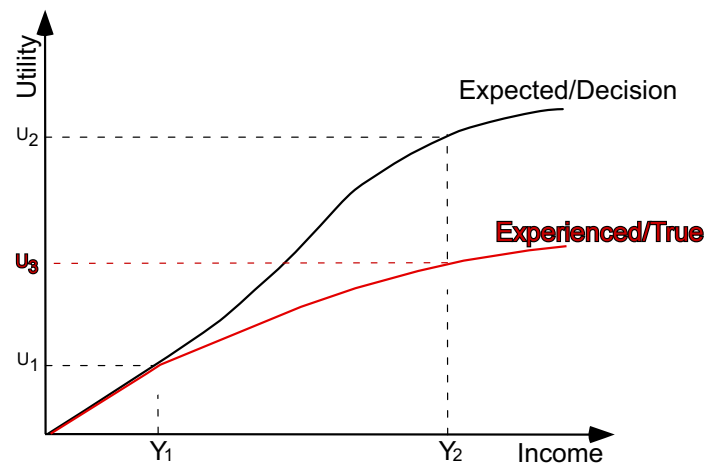

when a car was purchased-its effect on happiness is likely to decrease dramatically over time. PSID provides YEAR IN WHICH ACQUIRED FIRST CAR, but unfortunately there is no exact date.

Results are shown in the same Table 3 in columns d1-d4. These models exclude people without car in order to control for year of purchase $(2009,2010$, or 2011), and the sample size drops further.

Now, the base case is the reliable car category $(\$ 15-23 \mathrm{k})$. A luxury car only appears to bring more happiness than a reliable car in column $\mathrm{d} 1$, but in more elaborated subsequent specifications, its effect becomes insignificant. Also as expected, in all specifications (except d1), a very good car (\$23-35k) actually brings more happiness than a luxury car $(\$>35 \mathrm{k})$ further confirming that luxury car owners are not any happier. As expected, YEAR IN WHICH ACQUIRED FIRST CAR is positive- the more recent the purchase, the more happiness.

In addition, we have also tried adding a quadratic term for car price to find the inflection point, which is at $\$ 41 \mathrm{k}$ (using a full set of controls from column 4). Our conclusion is that, on average, the consumption of luxury cars does not contribute to happiness beyond a good frugal car $(\$ 15-35 \mathrm{k})$.

\section{Conclusion, limitations and future research}

There is not much happiness to be gained from car consumption when taking into account other happiness predictors. Especially junk cars $(\$ 0-5 \mathrm{k})$ are not contributing much to happiness. The optimal car consumption price range is somewhere between $\$ 15$ and 35k. This is a wide range. Arguably, results would differ by life circumstances or household characteristics-for instance indebtedness, proximity to workplace, occupation, and so forth-we leave it for the future research to explore it further. We find that there is no gain in happiness due to the consumption of luxury cars $(>\$ 35 \mathrm{k})$ over good frugal cars (\$15-35k), and if anything people consuming luxury cars are less happy than those consuming good frugal cars controlling for income and other happiness predictors. As suggested above, there are many explanations, but possibly the most convincing one is that of time loss. Again, a middle-class consumer (hourly 
wage after tax at \$10) who purchases a luxury car over a frugal car looses one year of time (assuming a 40-h work week, excluding weekends and holidays) to earn the additional $\$ 25 \mathrm{k}$ required to upgrade to a luxury car.

Fundamentally, it appears that we are about to witness or perhaps we have already witnessed with the 2008 financial crisis, the beginning of the end of consumerism era (again, in that year also car penetration of the US market peaked). There may be a cultural shift happening also with respect to cars-for instance, more people may be deciding that they do not really need a car. ${ }^{25}$ For a general discussion of a possible end of the consumerist era, see Ivanova (2011). Finally, keep in mind sustainability and environment. Not only luxury cars do not bring about more happiness than frugal cars, but they also pollute more (especially large SUVs), and this is another argument against luxury cars.

All this begs a question: If luxury cars don't make us happy, why do we buy them? One answer was suggested earlier-we buy them for other reasons-pride, prestige, power or superiority demonstration, and so forth. But there is also the happiness miscalculation explanation. A useful concept of expected $\mathrm{v}$ experienced utility (Kahneman et al. 1997) helps to illustrate it in Fig. 1. We decide on much of our consumption (cars, houses, etc.) and income (how hard and how long to work) based on the expected utility (or happiness) — and we are often (predictably) wrong-we think that higher income and consumption will make us happier than they actually do.

Another explanation given by Frank $(2004,2012)$ is that people tend to think mistakenly that they can outcompete others and do not realize that status or positional or luxury consumption is, by definition, a constant struggle that cannot be won. Positional goods improve happiness not because they are useful, but because they secure a better position in a society. But for there to be winners, there have to be losers, so the pie does not grow and society as a whole is not better off with more luxury cars. Yet another explanation is, as Galbraith has argued, that marketing or advertising makes people buy things (e.g., luxury cars) that they do not need (Dutt 2008).

A related puzzle is that humans have always wasted money on conspicuous consumption-not only post-Enlightenment Veblen's observations, but also, for instance, in ancient times, there is some condemnation of wasteful consumption as reported in the Bible. Likewise, there always have been smart voices to stop it, and probably forever will-perhaps, the fundamental problem with conspicuous consumption is that it signals status, power, superiority, and these attributes will always be sought after. Hence, while there may be a cultural shift happening away from luxury consumption as speculated above, significant luxury consumption may stay with us forever.

Although we do not explore this further here, perhaps, luxury consumption is one explanation for the Easterlin Paradox ${ }^{26}$ - that despite increase in income, we are not happier-maybe we simply spend our money unwisely-if we spend it on bowling or fishing, we could have been happier than wasting it on Lexuses and Audis.

\footnotetext{
${ }^{25}$ For instance, see http://www.nytimes.com/2009/10/22/automobiles/autospecial2/22CHANGE.html? pagewanted=all\&_r=0.

26 Note, however, that some scholars argue that there is no Easterlin Paradox, for instance see Veenhoven and Vergunst (2013).
} 
There are limitations, and at the same time directions for future research. First, causality can be addressed when more waves of data become available. Second, one can think of a quasi-experimental design-for instance, taking advantage of situations where a car is donated, inherited, or won in some lottery. Finally, it would be interesting to explore this relationship in other countries-Americans after all are in many ways exceptional. There exist good quality panel surveys containing happiness indicator, and possibly car information in other countries-for instance the German Socio-Economic Panel (GSOEP), and the British Household Panel Survey (BHPS). The present study examines the relationship in the US, where there is much of conspicuous consumption, inequality, and luxury cars. Also, authors live in the USA and are familiar with cars there. Yet, the advantage of other long-running panel datasets such as GSOEP or BHPS is that happiness can be modeled as a panel. This is important - the car is a proxy for values and preferences, maybe even personality, and hence, it may be other attributes of persons that correlate with the car that are responsible for its spurious effect on happiness. An important limitation in studies of luxury or conspicuous consumption is that of reverse causality as pointed out by Linssen et al. (2011) - people may consume luxuries because they are unhappy in the first place. Luxury shopping can arguably lighten up a day. Future research should explore reverse causality. Yet again, as persuasively pointed out by labor economist Andrew Oswald (e.g., Blanchflower and Oswald 2011; Oswald 2014), correlational studies are not without merit despite what many economists think-many scientific breakthroughs were first discovered in observational studies.

Conceptually, there are perhaps two key limitations. The first limitation is only apparent and arguably does not hold. It may appear that a car is like the other consumption goods, say a computer or a piece of furniture, and as such it may have a very short-lived and negligent effect on our happiness, because we consume so many of different items every day. Car is different, however. Keep in mind that the car is the second most expensive item most people buy in their lifetime, and an average person has to work for a year to earn it (a new medium-priced car) — it surely should increase happiness. But perhaps we consume so much that no single item, even a car, makes us happy any more. Perhaps, a person purchasing a Model T or a luxury car a century ago was happy. It may be so, but it does not change the fact that today there is little happiness from car consumption and no extra happiness from luxury car consumption. The second conceptual limitation is more serious. The high price of a car is only one indicator of luxury or conspicuous consumption. Luxury consumption can be defined in relative terms - for instance, a medium-priced Chevrolet Camaro or Ford Mustang could be categorized as luxury and conspicuous for working or even middle-class consumers. On the other hand, an expensive Porsche would be conspicuous or luxury for upper middle-class consumers, but Camaro or Mustang may not be conspicuous or luxury for them. This is a similar consideration to one discussed earlier that the richer the person, the less damaging and wasteful for that person luxury consumption is. Likewise, there are many poor people buying cars they cannot afford, and these cars are not necessarily very expensive. Finally, there can be luxury and conspicuous cars that are inexpensive-old Lexuses or Porsches, or frugal cars with extra conspicuous features such as rare animal leather seats. These limitations are also directions for future research. 
As most happiness research (including and following that of Bentham), this study ignores the fact that pleasures or happiness derived from different experiences are arguably qualitatively different_clearly happiness from driving a Lexus is different from that of having a child or eating a great hamburger, not only in intensity or level but also in quality. For some discussion of this important limitation, see Nussbaum (2012). There is, however, not much that can be done to alleviate this limitation using large scale surveys. Perhaps, a qualitative study such as a case study could shed additional light on this aspect of car consumption.

Most happiness studies lump together cognitive and affective aspects of happiness as we do here-one reason to do it is the lack of detailed multiple measures of a construct, and usually it is not a critical problem. It would be useful to distinguish between these two concepts with respect to luxury consumption. Perhaps, luxury consumption affects more happiness (affect) than life satisfaction (cognition). On the other hand, luxury consumption may also impact life satisfaction (cognition) by signaling accomplishment.

There are policy implications. As suggested here, many consumers, especially those with limited resources, may be better off not purchasing luxury cars. A straightforward way to improve consumption is for consumers to think critically about reasons for their purchases. Another solution to overconsumption of luxuries is a luxury tax. A similar measure is an increased personal income tax and redistribution. Piketty et al. (2011) have recently calculated that we can tax the rich as high as $80 \%$ and they will be fine and continue to work hard-it won't kill the goose lying golden eggs. On the other hand, as argued earlier, the higher the income, the less of a problem luxury consumption is for a consumer (not for society), because she needs to work less time to afford this waste (luxury consumption). In that sense, the richer you are, the less of a problem luxury consumption is for you. Increasing the gas tax has two advantages-it penalizes big and wasteful SUVs, and also penalizes driving a lot; a disadvantage is that it would disproportionately hurt the poor and middle class- the rich can afford it. Taxing luxury consumption would probably be the best solution. We do not advocate any of those solutions, but merely point out alternatives that could help people make better informed decisions, i.e., decisions that lead to greater happiness.

Again, a key problem with any luxury consumption is that it makes other people relatively deprived and results in consumption arms race (e.g., Frank 2012) — this is the reason for ridiculously expensive luxury cars that are severalfold as expensive as frugal cars without much substantive difference. For instance, both Toyota Corolla and Lexus IS have little substantive (technical) difference, ${ }^{27}$ they are even both made by the same company, Toyota, which created the Lexus so that it appears more exclusive and is not confused with the frugal Toyota, so that the price

\footnotetext{
27 Performance of Lexus may be 10-20\% better than Corolla's, but fuel efficiency is worse and Lexus is $100 \%$ more expensive. And much of the performance advantage is illusionary anyway-for instance, $140 \mathrm{mph}$ vs $115 \mathrm{mph}$ is meaningless because there are no public roads to drive at such speeds. Safety is about the same. For comparisons, see for instance http://cars.findthebest.com/compare/766-1250/2012Lexus-IS-250-vs-2012-Toyota-Corolla-L and http://carsort.com/compare/Lexus-IS-vs-Toyota-Corolla. Another example is a comparison of Toyota Highlander and Lexus RX-both being almost identical technically, yet Lexus being more expensive by $\$ 10 \mathrm{k}$ - a price paid for being conspicuous or wasteful. For comparisons see for instance http://www.autotrader.com/research/article/car-reviews/225342/2014toyota-highlander-vs-2014-lexus-rx-whats-the-difference.jsp.
} 
difference can be justified by buying a product that signifies that you are better than others. Most of the difference between two cars is fashion: e.g., colors and shapes. In short, as Veblen (2005a, b) observed a long time ago, such conspicuous consumption is a waste.

Open Access This article is distributed under the terms of the Creative Commons Attribution License which permits any use, distribution, and reproduction in any medium, provided the original author(s) and the source are credited.

\section{Appendix: Variable definitions and descriptive statistics}

See Table 4 and Fig. 2.

Table 4 Variable definitions

\begin{tabular}{|c|c|}
\hline Name & Description \\
\hline Happiness & $\begin{array}{l}\text { Please think about your life as a whole. How satisfied are you } \\
\text { with it? Are you completely satisfied, very satisfied, } \\
\text { somewhat satisfied, not very satisfied, or not at all satisfied? }\end{array}$ \\
\hline Car price & What was the total price of the vehicle?-FIRST VEHICLE \\
\hline Own car & If number of vehicles gt 0 \\
\hline Number of vehicles & $\begin{array}{l}\text { Altogether, how many vehicles do you (and your family living } \\
\text { there) own or lease (for your personal use)? }\end{array}$ \\
\hline Total family income & $\begin{array}{l}\text { The income reported here was collected in } 2011 \text { about tax year } \\
2010 \text {. Please note that this variable can contain negative } \\
\text { values. Negative values indicate a net loss, which in waves } \\
\text { prior to } 1994 \text { were bottom-coded at USD 1, as were zero } \\
\text { amounts. These losses occur as a result of business or farm } \\
\text { losses }\end{array}$ \\
\hline $\begin{array}{l}\text { Own a dwelling OR rent a dwelling } \\
\text { OR other than own/rent a }\end{array}$ & $\begin{array}{l}\text { Do (you (or anyone else in your family living there)/they (or } \\
\text { anyone else in the family living there)) own the } \\
\text { (apartment/mobile home/home), pay rent, or what? }\end{array}$ \\
\hline Number of children in household & $\begin{array}{l}\text { This variable represents the actual number of persons currently } \\
\text { in the FU who are neither Head nor Wife/"Wife," from } \\
\text { newborns through those } 17 \text { years of age, whether or not they } \\
\text { are actually children of the Head or Wife/"Wife" }\end{array}$ \\
\hline Health & $\begin{array}{l}\text { Now I have a few questions about (your/HEAD's) health. } \\
\text { Would you say (your/HEAD's) health in general is excellent, } \\
\text { very good, good, fair, or poor? }\end{array}$ \\
\hline Male & Sex of head \\
\hline Married & $\begin{array}{l}\text { Are you (HEAD) married, widowed, divorced, separated, or } \\
\text { have you never been married? }\end{array}$ \\
\hline Age & $\begin{array}{l}\text { This variable represents the actual age of the } 2011 \text { Head of the } \\
\text { FU. The minimum value is usually } 18 \text {, although in rare cases a } \\
\text { person under } 18 \text { might become Head. OR This variable } \\
\text { represents the actual age of the current Wife or "Wife" } \\
\text { (cohabiting female friend). Wives/"Wives" aged 14-16 are } \\
\text { rare }\end{array}$ \\
\hline Year in which acquired first car & $\begin{array}{l}\text { In what year did you (buy/lease/receive/acquire) it?-FIRST } \\
\text { VEHICLE }\end{array}$ \\
\hline
\end{tabular}



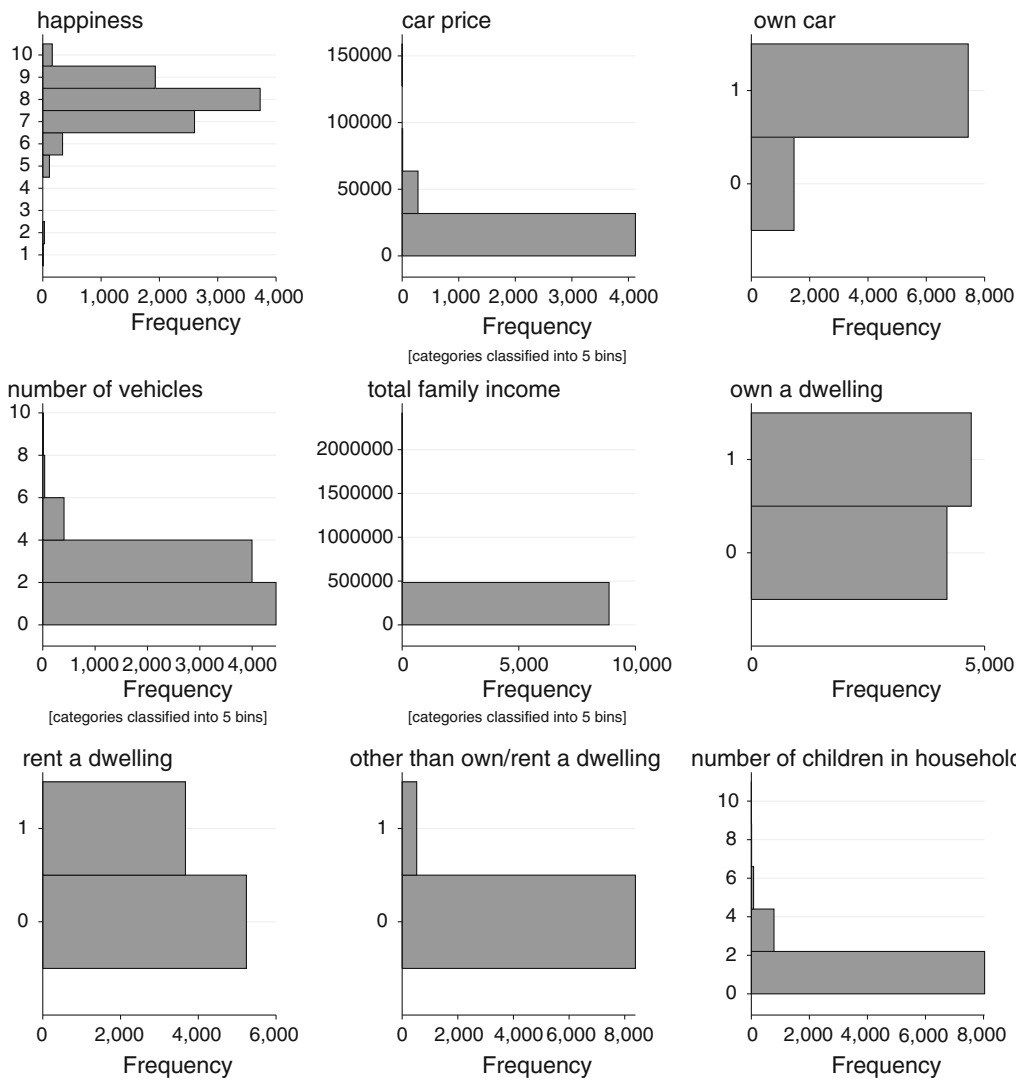

other than own/rent a dwelling

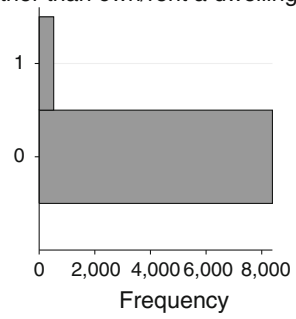

number of children in household
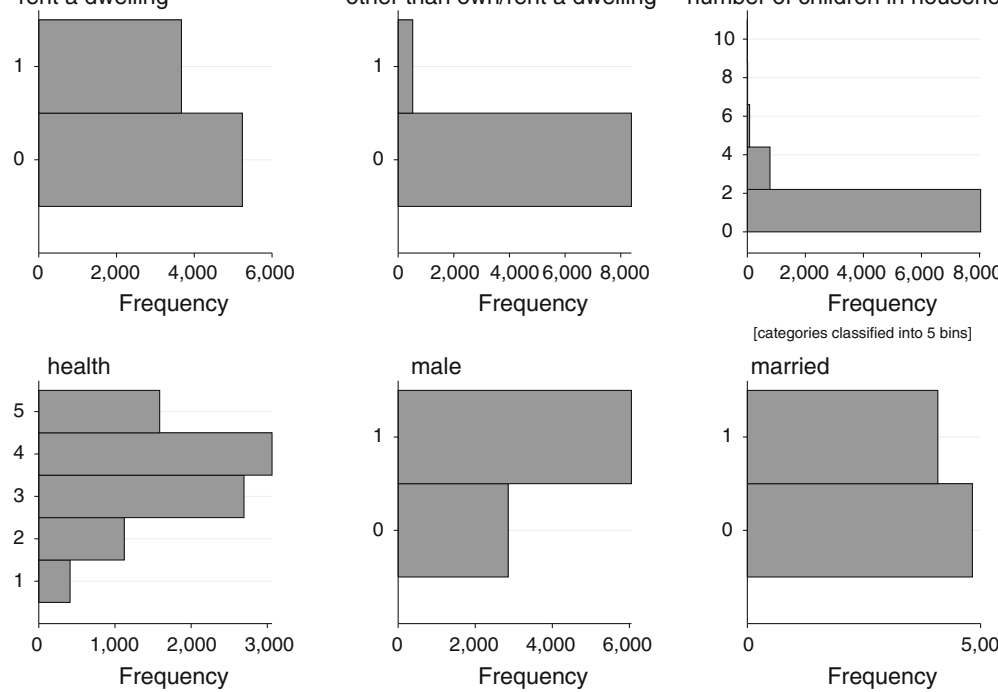
married
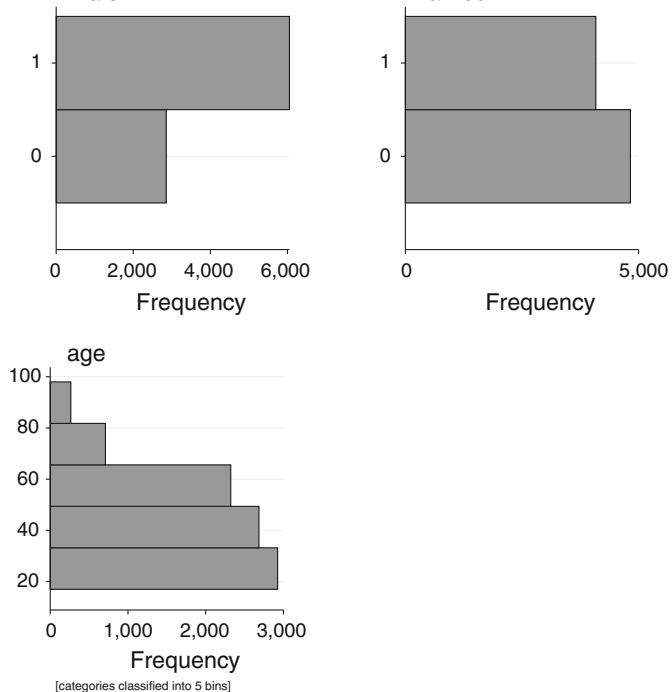

Fig. 2 Variables' distribution 


\section{References}

Alba JW, Williams EF (2013) Pleasure principles: a review of research on hedonic consumption. J Consum Psychol 23:2-18

Balducci A, Checchi D (2009) Happiness and quality of city life: the case of Milan, the richest Italian city. Int Plan Stud 14:25-64

Ballas D (2013) What makes a 'happy city'? Cities 32:S39-S50

Blanchflower DG, Oswald AJ (2011) International happiness: a new view on the measure of performance. Acad Manag Perspect 25:6-22

Brickman P, Coates D, Janoff-Buman R (1978) Lottery winners and accident victims: Is happiness relative? J Pers Soc Psychol 36:917-927

Daly H (2013) A further critique of growth economics. Ecol Econ 88:20-24

DeLeire T, Kalil A (2010) Does consumption buy happiness? Evidence from the United States. Int Rev Econ 57:163-176

Di Tella R, MacCulloch R (2006) Some uses of happiness data in economics. J Econ Perspect 20:25-46

Diener E (2013) The remarkable changes in the science of subjective well-being. Perspect Psychol Sci 8:663-666

Diener E, Diener M, Diener C (1995) Factors predicting the subjective well-being of nations. J Pers Soc Psychol 69:851-864

Diener E, Inglehart R, Tay L (2013) Theory and validity of life satisfaction scales. Soc Indic Res 112:497-527

Dorahy MJ, Lewis CA, Schumaker JF, Akuamoah-Boateng R, Duze M, Sibiya TE (1998) A crosscultural analysis of religion and life satisfaction. Ment Health Relig Cult 1:37-43

Duany A, Plater-Zyberk E, Speck J (2001) Suburban nation: the rise of sprawl and the decline of the American dream. North Point Press, New York

Durkheim E [1895] (1950) The rules of sociological method. The Free Press, New York

Dutt AK (2008) The dependence effect, consumption and happiness: Galbraith revisited. Rev Polit Econ 20:527-550

Economist T (2013a) Demand forecasts; distant peak car; carmakers worry that one day demand for cars will stop rising. But that is a long way off. The Economist. http://www.economist.com/news/specialreport/21576227-carmakers-worry-one-day-demand-cars-will-stop-rising-long-way

Economist T (2013b) Luxury cars; dreams on wheels; why everyone wants to be in the top end of the market. The Economist. http://www.economist.com/news/special-report/21576225-why-everyonewants-be-top-end-market-dreams-wheels

Erdogan B, Bauer TN, Truxillo DM, Mansfield LR (2012) Whistle while you work a review of the life satisfaction literature. J Manag 38:1038-1083

Ferrer-i-Carbonell A, Frijters P (2004) How important is methodology for the estimates of the determinants of happiness? Econ J 114:641-659

Frank R (2012) The Darwin economy: liberty, competition, and the common good. Princeton University Press, Princeton

Frank RH (2004) How not to buy happiness. Daedalus 133:69-79

Frank RH (2005) Does absolute income matter. In: Bruni L, Porta PL (eds) Economics and happiness. Oxford University Press, Oxford

Frank RH (2010) Hey, big spender: you need a surtax. New York Times. http://www.nytimes.com/2010/ 03/21/business/economy/21view.html?_r=0

Frey BS, Gallus J, Steiner L (2014) Open issues in happiness research. Int Rev Econ 61:115-125

Frey BS, Stutzer A (2002) What can economists learn from happiness research? J Econ Lit 40:402-435

Helliwell JF (2014) Good governance and national well-being: what are the linkages? In: 2014 wellbeing and public policy conference at Hamilton College

Hudders L, Pandelaere M (2012) The silver lining of materialism: the impact of luxury consumption on subjective well-being. J Happiness Stud 13:411-437

Ivanova MN (2011) Consumerism and the crisis: wither the'American Dream'? Crit Sociol 329-350

Jaffe E (2014) Car emissions vs. car crashes: Which one's deadlier? http://www.citylab.com/commute/ 2014/11/car-emissions-vs-car-crashes-which-ones-deadlier/382461/

Kahneman D, Krueger AB, Schkade DA, Schwarz N, Stone AA (2004) A survey method for characterizing daily life experience: the day reconstruction method. Science 306:1776-1780

Kahneman D, Wakker PP, Sarin R (1997) Back to Bentham? Explorations of experienced utility. Q J Econ 112:375-405 
Kallis G (2011) In defence of degrowth. Ecol Econ 70:873-880

Kallis G, Kerschner C, Martinez-Alier J (2012) The economics of degrowth. Ecol Econ 84:172-180

Kay JH (1997) Asphalt nation: how the automobile took over America, and how we can take it back. University of California Press, Oakland

Kumar A, Killingsworth MA, Gilovich T (2014) Waiting for Merlot anticipatory consumption of experiential and material purchases. Psychol Sci 0956797614546556

Layard R (2005) Happiness. Lessons from a new science. The Penguin Press, New York

Levitt SD, Dubner SJ (2010) Superfreakonomics: global cooling, patriotic prostitutes and why suicide bombers should buy life insurance. Penguin, UK

Linssen R, van Kempen L, Kraaykamp G (2011) Subjective well-being in rural India: the curse of conspicuous consumption. Soc Indic Res 101:57-72

McFerran B, Aquino K, Tracy JL (2014) Evidence for two facets of pride in consumption: findings from luxury brands. J Consum Psychol 24(4):455-471

McMahon J (2014) What Would Milton Friedman Do About Climate Change? Tax Carbon. Forbes. http://www.forbes.com/sites/jeffmcmahon/2014/10/12/what-would-milton-friedman-do-aboutclimate-change-tax-carbon/

Michalos A (1985) Multiple discrepancies theory (MDT). Soc Indic Res 16:347-413

Morris E (2007) From horse power to horsepower. ACCESS Mag 1. http://www.uctc.net/access/30/ Access $\% 2030 \% 20-\% 2002 \% 20-\% 20$ Horse\%20Power.pdf

Morris EA, GuerraE (2014) Mood and mode: does how we travel affect how we feel? Transportation 42(1):1-19

Myers DG (2000) The funds, friends, and faith of happy people. Am Psychol 55:56-67

Nussbaum MC (2012) Who is the happy warrior? Philosophy, happiness research, and public policy. Int Rev Econ 59:335-361

Okulicz-Kozaryn A (2011) Europeans work to live and Americans live to work (Who is happy to work more: Americans or Europeans?). J Happiness Stud 12:225-243

Oswald A (2014) Keynote II. In: 2014 wellbeing and public policy conference at Hamilton College

Pawson R, Tilley N (1997) Realistic evaluation. Sage, London

Piketty T, Saez E, Stantcheva S (2011) Optimal taxation of top labor incomes: a tale of three elasticities. Tech. rep, National Bureau of Economic Research

Proctor C, Linley P, Maltby J (2009) Youth life satisfaction: a review of the literature. J Happiness Stud 10:583-630

Putnam RD (2001) Bowling alone: the collapse and revival of American community. Simon and Schuster, New York

Ryzik M (2014) How uber is changing night life in Los Angeles. The New York Times. http://www. nytimes.com/2014/11/02/fashion/how-uber-is-changing-night-life-in-los-angeles.html

Steg L (2003) Can public transport compete with the private car? IATSS Res 27:27

Stiglitz J, Sen A, Fitoussi J (2009) Report by the commission on the measurement of economic performance and social progress. http://www.stiglitz-sen-fitoussi.fr

Sullivan P (2014) In sales of luxuries. Geography matters. New York Times. http://www.nytimes.com/ 2014/11/19/your-money/in-sales-of-luxuries-geography-matters-.html

Van den Bergh JC (2011) Environment versus growth-a criticism of "degrowth" and a plea for "agrowth". Ecol Econ 70:881-890

Veblen T (2005a) Conspicuous consumption, vol 38. ePenguin

Veblen T (2005b) The theory of the leisure class; an economic study of institutions. Aakar Books, Delhi

Veenhoven R (2008) Sociological theories of subjective well-being. In: Eid M, Larsen R (eds) The science of subjective well-being: a tribute to Ed Diener. The Guilford Press, New York, pp 44-61

Veenhoven R (2012) Evidence-based pursuit of happiness: What we should know, what we do know and what we can get to know. Tech. rep, EHERO

Veenhoven R (2014) Livability theory. Encycl Qual Life Well-Being Res 3645-3647

Veenhoven R, Ehrhardt J (1995) The cross-national pattern of happiness: test of predictions implied in three theories of happiness. Soc Indic Res 34:33-68

Veenhoven R, Vergunst F (2013) The Easterlin illusion: economic growth does go with greater happiness. Munich Pers RePEc Arch, Paper No 43983

Weinhold D (2012) The happiness-reducing costs of noise pollution. J Reg Sci 20(10):1-12

Welsch H (2005) Environment and happiness: valuation of air pollution using life satisfaction data. Ecol Econ 58:801-813 